\title{
PLASTIC PETROL: SYNTHESIS AND PERFORMATIVE STUDY
}

\author{
1N. B. Selukar, ${ }^{2}$ S. Khan, ${ }^{3 A}$. K. Thakur, ${ }^{4 R}$. S. Misal, 5 N. S. Gote \\ *Petrochemical Technology Department, \\ U.D.C.T., Sant Gadge Baba Amravati University, Amravati, M.S. (India) \\ Contact: 09370103307, 0721-2553337,E-mail: nbselukar@gmail.com \\ **Research Scholar, U.D.C.T., Sant Gadge Baba Amravati University, Amravati, \\ M.S. (India)
}

\begin{abstract}
Waste plastics are mostly land filled or incinerated; however, these methods are facing great social resistance because of environmental problems such as air pollution and soil contamination, as well as economical resistance due to the increase of space and disposal costs. In a long term neither the land filling nor the incineration solves the problem of wastes, because the suitable and safe depots are expensive, and the incineration stimulates the growing emission of harmful and greenhouse gases, e.g. NOx, Sox, COx etc. Accordingly, recycling has become an important issue worldwide. This method can be classified as energy recovery, material recycling and chemical recycling. Among them one of the prevalent alternative methods is the production of converted fuel and chemicals by means of the thermal or catalytic degradation of polymers.
\end{abstract}

A research work for systematic decomposition of waste plastic has been carried out by using liquid bed technique and the product is fractionated to obtain petrol, diesel and liquid bed. The product petrol is then subjected to load test in petrol rig to have performative study.

Key words: Break thermal power efficiency, Environment, Load test of petrol, Management of plastic waste, Plastic waste, Recycling of plastic waste,

\section{INTRODUCTION}

In 'western' countries, plastic consumption has grown at a tremendous rate over the past two or three decades. In the 'consumer' societies of Europe and America, scarce petroleum resources are used for producing an enormous variety of plastics for an even wider variety of products. Many of the applications are for products with a life-cycle of less than one year and then the vast majority of these plastics are then discarded. In most instances reclamation of this plastic waste is simply not economically viable. 
$7,8,9,10,11,12$ One of the method to deal plastic waste is the chemical recycling. The chemical recycling processes can be classified into three main areas:

1. Recycling to fuels [gasoline, liquefied petroleum gas (LPG) and diesel oil],

2. Recycling to monomers,

3. Recycling to industrial chemicals.

\section{MATERIALS AND METHODS}

$13,14,15$ The main aim of this research work is to obtain fuel from waste plastic and to carry out the performative study of this petrol in petrol rig. The waste plastic selected was the polystyrene. Polystyrene is used to manufacture disposable cup and plates, fast food boxes, thermocol, etc. The technique used for conversion of waste plastic into fuel is the liquid bed technique. As the primary experimental studies shows that this technique is able to give high quantity of fuel product and also recover the liquid bed. The experiment is carried out in the laboratory by using glass reactor. This reactor having an arrangement to record the reaction mass temperature as well as temperature of product vapor's going for condensation. Thus this arrangement is able to give decomposition and fractionation at desired temperature in a single step. In this work the liquid bed adopted is the kerosene with boiling range $200-250^{\circ} \mathrm{C}$. Here electrical heating device is used to provide high temperature and dimmerstate is used to control and maintain temperature of reactor. For proper coiling, two stage condensation system is used.

16,17Testing methods used for characterization of product liquid, liquid bed are as follows:

1. Specific gravity, API gravity and density determination,

2. Flash point determination,

3. Viscosity determination,

4. Acid value determination,

5. Saponification value determination,

6. Conradson carbon residue determination, 
7. Aniline point determination,

8. Copper corrosion test,

9. Determination of water content,

10. Color inspection.

\section{OBSERVATIONS}

The observations for various tests for feed liquid bed, product liquid bed and product petrol and diesel are as shown below:

\begin{tabular}{|c|c|c|c|c|c|}
\hline $\begin{array}{l}\text { S. } \\
\text { N. }\end{array}$ & Properties & Petrol & $\begin{array}{c}\text { Kerosene } \\
\text { (Product bed) }\end{array}$ & Diesel & $\begin{array}{l}\text { Feed Liquid } \\
\text { Bed }\end{array}$ \\
\hline 1 & Specific gravity, at $38^{\circ} \mathrm{C}$ & 0.7751 & 0.8076 & 0.9411 & 0.7928 \\
\hline 2 & API gravity & 33.59 & 43.979 & 18.8479 & 47 \\
\hline 3 & Viscosity, cst $\left(40^{\circ} \mathrm{C}\right)$ & 1.0658 & 1.3209 & 2.9747 & --- \\
\hline 4 & Aniline point, ${ }^{\circ} \mathrm{C}$ & Below $1.5^{\circ} \mathrm{C}$ & $54^{\circ} \mathrm{C}$ & $31^{\circ} \mathrm{C}$ & $63^{\circ} \mathrm{C}$ \\
\hline 5 & Flash point, ${ }^{\circ} \mathrm{C}$ & --- & $72^{\circ} \mathrm{C}$ & $108^{\circ} \mathrm{C}$ & $72^{\circ} \mathrm{C}$ \\
\hline 6 & $\begin{array}{l}\text { Conradson carbon } \\
\text { residue, wt } \%\end{array}$ & 0.01614 & 0.02288 & 0.0187 & 0.0059 \\
\hline 7 & Refractive index at $27^{\circ} \mathrm{C}$ & 1.5003 & 1.4582 & 1.5376 & 1.4491 \\
\hline 8 & $\begin{array}{l}\text { ASTM distillation } \\
\text { IBP }{ }^{\circ} \mathrm{C} \\
10 \% \\
30 \% \\
50 \% \\
90 \% \\
\text { FBP C } \\
\text { MAX. Recovery (ml) }\end{array}$ & $\begin{array}{c}145 \\
150 \\
154 \\
159 \\
209 \\
215 \\
98 \\
\end{array}$ & $\begin{array}{c}192 \\
200 \\
211 \\
220 \\
250 \\
253 \\
97 \\
\end{array}$ & $\begin{array}{c}251 \\
256 \\
274 \\
296 \\
310 \\
365 \\
97 \\
\end{array}$ & $\begin{array}{c}190 \\
200 \\
208 \\
216 \\
245 \\
256 \\
97 \\
\end{array}$ \\
\hline 9 & $\begin{array}{l}\text { Moisture content } \\
\% \\
\mathrm{Ppm} \\
\mathrm{Mg} \text { of } \mathrm{H}_{2} \mathrm{O}\end{array}$ & $\begin{array}{l}0.03028 \\
302.79 \\
2.5454\end{array}$ & $\begin{array}{c}0.01494 \\
149.43 \\
1.1818\end{array}$ & $\begin{array}{c}0.02412 \\
241.29 \\
2.227\end{array}$ & $\begin{array}{c}0.019260 \\
192.6040 \\
1.5000\end{array}$ \\
\hline 10 & $\begin{array}{l}\text { Copper strip corrosion at } \\
50^{\circ} \mathrm{C}, 3 \text { hours }\end{array}$ & $\begin{array}{l}\text { Not worse than } \\
\text { no. } 1\end{array}$ & $\begin{array}{l}\text { Not worse than } \\
\text { no. } 1\end{array}$ & $\begin{array}{l}\text { Not worse } \\
\text { than no. } 1\end{array}$ & $\begin{array}{c}\text { Not worse than } \\
\text { no. } 1\end{array}$ \\
\hline
\end{tabular}

18To study the petrol obtained is really workable or not, the load test of product petrol is carried out in petrol rig and data obtained is compared with the mineral petrol data at identical conditions.

\section{Observation and data given:}

1. Cylinder bore $(D)=52 \mathrm{~mm}$,

2. Stroke length $(\mathrm{L})=51.8 \mathrm{~mm}$,

3. Water density $(\square \mathrm{w})=1000 \mathrm{~kg} / \mathrm{m}^{3}$,

4. Calorific value of sample (mineral petrol) $=42000 \mathrm{KJ} / \mathrm{kg}$ 
5. Acceleration due to gravity $(\mathrm{g})=9.81 \mathrm{~m} / \mathrm{s}^{2}$,

6. Air density $(\square \mathrm{a})=1.2 \mathrm{~kg} / \mathrm{m}^{3}$,

7. Room temperature $\left(\mathrm{T}_{1}\right)=34^{\circ} \mathrm{C}$

\section{A] For Mineral Petrol:}

1. Density of petrol sample $(\square \mathrm{f})=0.7 \mathrm{~kg} /$ litre,

2. Calorific value (C.V.) $=42000 \mathrm{KJ} / \mathrm{kg}$

Observation table for mineral petrol sample:

\begin{tabular}{|c|c|c|c|c|c|c|}
\hline S.N. & $\mathbf{h}_{\mathbf{1}}$ & $\mathbf{h}_{\mathbf{2}}$ & $\mathbf{R P M}$ & Load (kg) & $\begin{array}{c}\text { Time } \\
(\mathbf{s e c})\end{array}$ & $\begin{array}{c}\text { Exhaust Temperature } \\
\left({ }^{\mathbf{O}} \mathbf{F}\right)\end{array}$ \\
\hline 1 & 15 & -20 & 2500 & 0.5 & 59 & 535 \\
\hline 2 & 15 & -20 & 2500 & 1.0 & 51 & 545 \\
\hline 3 & 15 & -20 & 2500 & 1.3 & 44 & 548 \\
\hline 4 & 15 & -20 & 2500 & 1.5 & 42 & 552 \\
\hline
\end{tabular}

\section{B] For Plastic Petrol:}

1. Density of petrol sample $(\square \mathrm{f})=0.77 \mathrm{~kg} /$ litre,

2. Calorific value (C.V.) $=39570 \mathrm{KJ} / \mathrm{kg}$

Observation table for plastic petrol sample:

\begin{tabular}{|c|c|c|c|c|c|c|}
\hline S.N. & $\mathbf{h}_{\mathbf{1}}$ & $\mathbf{h}_{\mathbf{2}}$ & $\mathbf{R P M}$ & $\begin{array}{c}\text { Load } \\
\mathbf{( k g )}\end{array}$ & $\begin{array}{c}\text { Time } \\
(\mathbf{s e c} .)\end{array}$ & $\begin{array}{c}\text { Exhaust Temperature } \\
\mathbf{( \mathbf { O F } )}\end{array}$ \\
\hline 1 & 15 & -20 & 2500 & 0.5 & 63 & 535 \\
\hline 2 & 15 & -20 & 2500 & 1.0 & 56 & 545 \\
\hline 3 & 15 & -20 & 2500 & 1.3 & 49 & 548 \\
\hline 4 & 15 & -20 & 2500 & 1.5 & 46 & 552 \\
\hline
\end{tabular}

\section{Calculations}

1. Air mass flow rate (Ma): $\mathrm{Kg} / \mathrm{hr}$.

a) $\quad$ Area of orifice $=\frac{\pi}{4} \mathrm{xd}^{2}$

Where, $\mathrm{d}=$ Orifice diameter $=0.01525 \mathrm{~m}, \mathrm{~A}_{0}=1.8256 \times 10^{-4} \mathrm{~m}^{2}$ 
b) Manometer head (Ha):

$$
\begin{aligned}
\mathrm{Ha} & =\frac{\frac{\mathrm{hw}}{100} \times \rho \mathrm{w}}{\rho \mathrm{a}} \\
\mathrm{hw} & =\mathrm{h}_{1}-\mathrm{h}_{2}=15-(-20)=35 \mathrm{~cm} \\
\rho \mathrm{w} & =1000 \mathrm{~kg} / \mathrm{m}^{3} \\
\rho \mathrm{a} & =1.2 \mathrm{~kg} / \mathrm{m}^{3} \\
\mathrm{Ha} & =291.66 \mathrm{~m}
\end{aligned}
$$

c) Mass flow rate of air:

$\mathrm{Ma}=\mathrm{A}_{0} \times \mathrm{C}_{\mathrm{d}} \times 3600 \times \rho \mathrm{Na}(\mathrm{Ha} \times 2 \times \mathrm{g})^{0.5} \mathrm{~kg} / \mathrm{hr}$

Here $\mathrm{C}_{\mathrm{d}}=$ constant for engine $=0.62$

$$
\begin{aligned}
\mathrm{Ma} & =2.2344 \times(\mathrm{Ha})^{0.5} \\
& =38 \mathrm{~kg} / \mathrm{hr} .
\end{aligned}
$$

\section{Break Power:}

$$
\begin{aligned}
& \mathrm{BP}=\frac{(2 \pi \times \mathrm{N} \times \mathrm{W} \times \mathrm{R} \times \mathrm{g})}{60000} \times \eta \mathrm{d} \\
& \mathrm{BP}=\frac{(\mathrm{w} \times \mathrm{N})}{4599}
\end{aligned}
$$

Where, $\quad \mathrm{W}=$ Load shown in spring balance in $\mathrm{kg}$,

$\mathrm{R}=$ Torque $\operatorname{arm}=0.18$ meter,

$\eta \mathrm{d}=$ Efficiency of eddy current dynamometer $=0.85$, $\mathrm{N}=$ Engine speed in RPM,

\section{Specific fuel consumption (SFC in $\mathrm{kg} / \mathrm{kw}-\mathrm{hr}$ ):}

$\mathrm{SFC}=\frac{\mathrm{TFC}}{\mathrm{BP}}$

4. Air fuel ratio $A / F$ :

$$
\begin{aligned}
& \mathrm{A} / \mathrm{F}=\frac{\mathrm{Ma}}{\mathrm{TFC}}=\frac{38}{\mathrm{TFC}} \\
& \boldsymbol{\rho}_{\mathrm{f}}=0.7 \mathrm{~kg} / \text { liter, } \mathrm{CV}=42000 \mathrm{KJ} / \mathrm{kg}
\end{aligned}
$$

5. Total fuel consumption (TFC in $\mathbf{~ g g} /$ hour):

$$
\mathrm{TFC}=\frac{\left(10 \times 3600 \times \rho_{\mathrm{f}}\right)}{(\mathrm{t} \times 1000)}
$$

Where, $\quad 10=$ Fuel consumed in cc,

$$
\begin{aligned}
& \rho_{\mathrm{f}}=\text { Fuel density }=0.7 \mathrm{~kg} / \mathrm{liter}, \\
& \mathrm{T}=\text { time for } 10 \mathrm{c} \text { fuel consumed, } \\
& \mathrm{TFC}=25.2 / \mathrm{t}
\end{aligned}
$$




\section{Break thermal efficiency $\square \mathbf{b} \%$ :}

$\eta \mathrm{b}=\frac{(\mathrm{BP} \times 100 \times 3600)}{\text { Heat supplied }}$

Heat supplied $=\mathrm{TFC} \times$ Calorific value

$\mathrm{CV}=42000 \mathrm{KJ} / \mathrm{kg}$

MATERIAL BALANCE

\begin{tabular}{|c|c|c|c|c|c|}
\hline Feed & $\begin{array}{c}\text { Petrol } \\
\text { in } \mathbf{~ m} \mathbf{l}\end{array}$ & $\begin{array}{c}\text { Kerosene } \\
\text { in } \mathbf{~ m} \mathbf{l}\end{array}$ & $\begin{array}{c}\text { Diesel } \\
\text { in ml }\end{array}$ & $\begin{array}{c}\text { Residue } \\
\text { in gram }\end{array}$ & Gases \\
\hline $\begin{array}{c}\text { Waste plastic } 100 \mathrm{gm} \text { and } \\
\text { Liquid Bed } 100 \mathrm{ml}\end{array}$ & 22.5 & 101 & 75 & 7.3252 & Traces \\
\hline
\end{tabular}

\section{RESULT AND DISCUSSION}

Result: The various values for TFC, SFC, A/F and Break Thermal Efficiency obtained for mineral petrol and plastic petrol are tabulated as follows:

\begin{tabular}{|c|c|c|c|c|c|c|c|c|c|}
\hline Sample & $\begin{array}{l}\text { Density } \\
\text { (kg/lit.) }\end{array}$ & $\begin{array}{c}\text { Calorific } \\
\text { Value } \\
\text { (KJ/Kg) }\end{array}$ & $\begin{array}{c}\text { Load } \\
\text { (kg) }\end{array}$ & $\begin{array}{l}\text { B.P. } \\
\text { (KW) }\end{array}$ & $\begin{array}{c}\text { TFC } \\
(\mathrm{Kg} / \mathbf{h r} .)\end{array}$ & $\begin{array}{c}\text { SFC } \\
(\mathbf{k g} / \mathbf{k} \\
\mathrm{W}-\mathrm{hr}) \\
\end{array}$ & $\mathbf{A} / \mathbf{F}$ & $\begin{array}{c}\text { Heat } \\
\text { supplied } \\
\text { (KJ/kg) }\end{array}$ & $\begin{array}{c}\text { Break } \\
\text { Thermal } \\
\text { Efficiency }\end{array}$ \\
\hline \multirow{4}{*}{ A } & \multirow{4}{*}{0.7} & \multirow{4}{*}{42000} & 0.5 & 0.2717 & 0.4271 & 1.57 & 80.67 & 17938.2 & 5.45 \\
\hline & & & 1.0 & 0.5438 & 0.4941 & 0.9 & 76.90 & 20752.2 & 9.41 \\
\hline & & & 1.3 & 0.7070 & 0.5727 & 0.81 & 66.35 & 24053.4 & 10.58 \\
\hline & & & 1.5 & 0.815 & 0.6 & 0.73 & 63.33 & 25200 & 11.73 \\
\hline \multirow{4}{*}{ D } & \multirow{4}{*}{0.77} & \multirow{4}{*}{39570} & 0.5 & 0.2717 & 0.44 & 1.61 & 86.33 & 18480 & 5.33 \\
\hline & & & 1.0 & 0.5438 & 0.495 & 0.91 & 76.76 & 20790 & 9.48 \\
\hline & & & 1.3 & 0.7070 & 0.5657 & 0.8 & 67.17 & 23795.4 & 10.79 \\
\hline & & & 1.5 & 0.815 & 0.6026 & 0.7393 & 63.06 & 25309.2 & 11.68 \\
\hline
\end{tabular}

\section{Discussion:}

1. From above observation it is clear that the waste plastic able to give the liquid product which can fractionated into petrol, recover kerosene bed and diesel.

2. Here the fractionation was carried out by using ASTM distillation. The fraction with boiling point up to $200^{\circ} \mathrm{C}$ is known as petrol. The fraction with boiling range $200-250^{\circ} \mathrm{C}$ is known as liquid bed, and the fraction with boiling point range above $250^{\circ} \mathrm{C}$ is known as diesel.

3. From the high specific gravity and low aniline point of product petrol and diesel as compared with IS specification (IS norms for specific gravity of petrol 
is $0.70-0.72)$ indicate that the product petrol and diesel consists of high percentage of aromatic hydrocarbons.

4. Flash point value for product diesel is quite higher than the standard value of diesel. This is due to the boiling point range. Actually flash point is related to lower hydrocarbon (that is IBP to $10 \%$ range hydrocarbon). Here kerosene and diesel taken as higher range (kerosene $200-250^{\circ} \mathrm{C}$ ) and diesel more than $250^{\circ} \mathrm{C}$. Hence, there are higher value of flash point for kerosene and diesel.

5. Break power: As load increases break power also increases, but the break power is same for pure petrol and petrol obtained from plastic for respective load, because break power is the unusable power output of the engine which does not depend on power required to fuel.

6. Fuel test time: Fuel test time for $10 \mathrm{cc}$ fuel decreases as load increases, but decrease in time is more for pure petrol than the petrol obtained from plastic.

7. Total fuel consumption: As load increases the total fuel consumption increases, but increase in total fuel consumption is more for pure petrol than petrol obtained from plastic for respective load.

8. Specific fuel consumption: As load increases the specific fuel consumption decreases, but the decrease in pure petrol is more than the petrol obtained from plastic for respective load.

9. Air to fuel ratio: As load increases the air to fuel ratio decreases, but for pure petrol air to fuel ratio decreases more than the petrol obtained from plastic.

10. Break thermal efficiency: As load increases the break thermal efficiency increases, but increase in efficiency is more in pure petrol than the petrol obtained from plastic.

\section{CONCLUSIONS}

1. From this work it is clear that the waste plastic able to give the high amount of liquid fuel range product by using liquid bed, which can be fractionated to petrol, diesel and recover kerosene bed. 
2. Use of liquid bed able to give high yield of liquid fuel, 100 gm polystyrene waste able to give nearly $100 \mathrm{ml}$ liquid product.

3. The product fuel i.e. petrol and diesel able to show all the characteristics prescribed for these fuels.

4. From the comparative performative data for mineral petrol and plastic petrol, we can conclude that the plastic petrol able to run the engine and have nearly same break thermal efficiency as that of mineral petrol.

5. Finally it can be concluded that the plastic petrol is workable and give the same performance as that of mineral petrol in all aspects.

\section{REFERENCES}

http:/ / www.win-fong.com/en/classificationw.html

http: / / saferenvironment.wordpress.com/2008/10/06/plastic-wastes-reduce-

reuse-and-recycle-of-plastics-are-essential-to-make-environment-greenerand-safer/

http://www.prokerala.com/going-green/ill-effects-of-plastic.php

http://www.envis-icpe.com/overview plastics.html

http:/ /www.globalspec.com/reference/14111/121073/chapter-d1-5-physical

Aguado. J, Serrano. D. P, San Miguel,(2006). "European Trends in the Feedstock Recycling of Plastic Wastes", Global NEST JI, Vol. X, Page No.1-7.

Strong A B, (2000). "Plastics Materials and Processing", Prentice-Hall, New Jersey, USA.

http://en.howtopedia.org/wiki/How to Recycle Plastics

http:/ / saferenvironment.wordpress.com/2008/10/06/plastic-wastes-

$\% \mathrm{E} 2 \% 80 \% 93-$ reduce-reuse-and-recycle-of-plastics-are-essential-to-make-

environment-greener-and-safer/

http: / / www.gprecycling.co.za/social-responsibility/

ICPE projects published by Environmental Information System in the site, http:/ / www.envis-icpe.com/recyclingproiects.html 
http://www.geo.hunter.cuny.edu/ mclarke/IntroMSWincineration.htm

Dr. A. Tukker, Ing.H.de Groot, Ir.L. Simons, Ir.S.Wicgersma (December 1999). "Chemical recycling of Plastic waste (PVC and other resins)", TNO Report, TNO Institute of Strategy, Technology and Policy, The Netherlands.

Muhammad N. Almustapha and John M. Andresen; (June 2012). Recovery of valuable chemicals from HDPE polymer; International Journal of Environmental Science and Development; Vol.3, No.3.

Paula A. costa, Filomena J. Pinto, Ana. M. Ramos, Ibrahim K. Gulyurtlu, Isabel A. Cabrita, and Maria S. Bernardo, (2007). "Kinetic evolution of pyrolysis of polyethylene waste", Energy and Fuels, Vol.21, No.5.

Hee Taik Kim and Sea Cheon Oh; (June 2005). Kinetics Of Thermal Degradation Of Waste Polymer; J. Ind. Eng. Chem., Vol.11, No.5.

"Standard Method for Analysis of Petroleum and Related Product 1993", Institute of Petroleum, London, Vol. 1, Published by John Wiley and Son (1993).

"Standard Method for Analysis of Petroleum and Related Product 1993", Institute of Petroleum, London, Vol. 2, Published by John Wiley and Son (1993).

Instruction manual for petrol engine test rig by Dewale Engineering system, Bangalore, India (2008). 